\title{
The Optical Properties of Europium-doped Zinc Selenide Films
}

\author{
D.M. Jeroh*, A.J. Ekpunobi, D.N. Okoli \\ Nnamdi Azikiwe University, Anambra State, Nigeria
}

(Received 01 May 2020; revised manuscript received 15 October 2020; published online 25 October 2020)

\begin{abstract}
Europium-doped ZnSe films were sprayed on glass substrates electrostatically. Keeping other deposition parameters such as flow rate of precursor solution, spray volume, voltage and distance of nozzle to substrate constant, temperature was varied from about $300{ }^{\circ} \mathrm{C}$ and $400{ }^{\circ} \mathrm{C}$ with an interval of 25 degrees. Optical studies at different temperatures are presented. Thickness of the films obtained by surface profile indicates nanosizes of 50,100,150, 75 and $60 \mathrm{~nm}$ in the considered temperature range. Optical studies reveal high transparency, very minimal absorption and reflection characteristics of ZnSe:Eu films in the visible region. Absorption peaks visible at $250 \mathrm{~nm}$ suggest the occurrence of defect state near the band edge. Large absorption coefficient suggesting evidence of high density of states for ZnSe:Eu is observed. High transmittance results suggest the films suitability in coating materials that are required to exhibit high transparency for laser applications, while low reflectance values and large refractive index reveal the films could be applicable in solar cell coatings that require high efficiency and in manufacturing optoelectronic devices. Higher optical conductivity at photon energies above $3 \mathrm{eV}$ is evident. Steep increase in extinction coefficient with photon energy indicates the probability of raising the electron transfer across the mobility gap with high photon energy and greater attenuation of light. Band gap investigation of ZnSe:Eu films reveals a strong blue-shift ( $3.01 \mathrm{eV}$ to $3.12 \mathrm{eV}$ ) from the bulk ZnSe $(2.72 \mathrm{eV})$ band gap.
\end{abstract}

Keywords: Zinc selenide, Europium, Nanofilms, Spray pyrolysis, Optical studies.

\section{INTRODUCTION}

The bulk of devices in the electronics industries rely more on semiconductors as their raw materials for manufacturing purposes. II-VI semiconductors have been vastly researched possibly on account of their numerous applications in device manufacturing technology. It is very essential to explore the properties (optical) of materials in order to establish their energy (band) gap and process of transition so as to suggest suitable relevance of the films [1]. Zinc selenide is characterized by a wide energy (band) gap of about $2.7 \mathrm{eV}$. Due to the properties exhibited by this material, it has found applications in a range of devices such as optoelectronic devices, solar cell production and so on. ZnSe films have earlier been prepared by electrodeposition [2], solution growth [3,4], spray pyrolysis [5], thermal evaporation [6], RF magnetron sputtering [7], etc. Some research articles on Eu-doped $\mathrm{ZnO}$ and $\mathrm{ZnS}$ films [8-9] exist. However, little report is available on Eu-doped ZnSe $[10,11]$ films by solvothermal and CSVC deposition techniques.

Spray pyrolysis (electrostatic) was considered to grow Eu-doped ZnSe nanofilms taking into account its novelty in this regard. When compared to conventional spray pyrolysis technique, electrostatic spray pyrolysis is capable of producing fine and extremely tiny droplets which is the desire of this research. Also, when compared with sophisticated techniques such as pulsedlaser deposition, molecular beam epitaxy, sputtering, vacuum evaporation, this technique was desired to dope the films because it proffers a clear-cut approach of doping films by the effortless insertion of the expected dopant to the spray mixture. This technique also comprises of an easy set-up and much technicality is not man- datory when using this process. The core motivation of this research is to examine only the properties (optical) of $\mathrm{ZnSe}: \mathrm{Eu}$ films in detail and carefully suggest their suitable relevance based on the obtained results. Zinc selenide (ZnSe) has been studied extensively; hence we are of the view that doping ZnSe with europium could well improve the properties (optical) and possibly introduce new functions of the material. This assumption is so considering the luminescent property exhibited by europium which has the prospect of improving the properties (optical) of $\mathrm{ZnSe}$, which of course may open novel sections of application of the material.

\section{MATERIALS AND SUBSTRATES PREPARATION}

The preparatory materials for this communication are zinc acetate (source of zinc ion), hydrochloric acid $(\mathrm{HCl})$ which served as a stabilizing agent, selenium dioxide (source of selenium ion) and europium (III) oxide (source of europium ion). Prior to deposition of $\mathrm{ZnSe}: \mathrm{Eu}$ films, the glass slides which served as substrates were ultrasonically cleaned in a sonicator for $12 \mathrm{~min}$ and rinsed in water (distilled) and eventually refluxed (using a soxhlet apparatus). After refluxing, the glass substrates were left to dry and placed in a clean air-tight glass jar to avoid contamination of any kind.

\section{EXPERIMENTAL PROCEDURE}

A $0.4 \mathrm{M}$ solution comprising zinc acetate (dehydrate) and selenium dioxide were mixed in equal proportions inside a beaker. The solution was stabilized by the simple addition of little drops of concentrated $\mathrm{HCl}$. The spray mixture was stirred continuously by a mag-

\footnotetext{
* jeruaye@gmail.com
} 
netic stirrer hot plate for 15 min to ensure uniformity of the solution. 10 wt. \% of europium (III) oxide was simply added to the spray mixture and continuously stirred for $30 \mathrm{~min}$ before being sprayed directly onto the heated glass slides through a nozzle (syringe) at separate growth/deposition temperatures between $300{ }^{\circ} \mathrm{C}$ and $400{ }^{\circ} \mathrm{C}$. On decomposition, light pinkish $\mathrm{ZnSe}: \mathrm{Eu}$ films were formed on the glass substrates. The temperature attained by the glass slides was provided externally and measurement obtained with a $k$ thermocouple connected beneath the heating plate. During the process of growth, flow-rate was kept constant at $400 \mu \mathrm{l} / \mathrm{spray,}$ nozzle-substrate distance was optimized at $5.67 \mathrm{~mm}$ at a steady voltage of $3.5 \mathrm{kV}$.

The proposed reaction mechanism for growing ZnSe:Eu films is described as follows:

Adding $\mathrm{HCl}$ as a stabilizer to zinc acetate releases the $\mathrm{Zn}^{2+}$ ion as indicated in equation (1):

$$
\begin{gathered}
\mathrm{Zn}\left(\mathrm{CH}_{3} \mathrm{COO}\right)_{2} .2 \mathrm{H}_{2} \mathrm{O}+2 \mathrm{HCl} \rightarrow \mathrm{Zn}^{2+}+ \\
2\left[\mathrm{CH}_{3} \mathrm{COOH}\right]+2 \mathrm{H}_{2} \mathrm{O}+2 \mathrm{Cl} .
\end{gathered}
$$

When selenium dioxide is included into the reaction bath, it dissociates forming the complex $\mathrm{Se}^{2-}$ as indicated in equation (2):

$$
\mathrm{SeO}_{2} \rightarrow \mathrm{Se}^{2-}+\mathrm{O}_{2}
$$

Europium trioxide dissociates in the reaction bath forming $\mathrm{Eu}^{3+}$ complex according to equation (3):

$$
\mathrm{Eu}_{2} \mathrm{O}_{3} \rightarrow 4 \mathrm{Eu}^{3+}+3 \mathrm{O}_{2} .
$$

The combined reaction of the ions in equations (1), (2) and (3) undergoes pyrolytic decomposition, resulting in ZnSe:Eu films according to equation (4):

$$
\mathrm{Zn}^{2+}+\mathrm{Se}^{2-}+\mathrm{Eu}^{3+} \rightarrow \mathrm{ZnSe}: \mathrm{Eu} \downarrow
$$

\section{RESULTS AND ANALYSIS}

\subsection{Thickness Measurement}

ZnSe:Eu film thicknesses were acquired from a stylus profiler (Model: Veeko Dektak 150) at room temperature. For deposition temperatures of 300, 325, 350, 375 and $400{ }^{\circ} \mathrm{C}$, the corresponding thicknesses are 50 , $100,150,75$ and $60 \mathrm{~nm}$, respectively. The reduction in film thickness at increased temperatures might be as a result of the reduction in mass transfer of the precursor to the substrate due to gas convection from the chamber, pushing several of the droplets away from the substrate [12].

\subsection{Optical Studies}

The optical absorption spectra of ZnSe:Eu films in this research were determined from a UV-Vis spectrophotometer (Cary Model) in the wavelength region of $200 \mathrm{~nm}$ to $800 \mathrm{~nm}$. The absorption spectra of ZnSe:Eu films determined at various temperatures are displayed in Fig. 1.

ZnSe:Eu films exhibited extremely poor absorption in the entire visible region (Fig. 1). ZnSe:Eu films displayed absorption peaks around $250 \mathrm{~nm}$. These peaks may be associated with the absorption of $\mathrm{SeO}_{2}$ since selenium is unstable in air and therefore reacts with oxygen in air [5] and also due to some defect states that may have occurred within the band edge [13]. All the absorption curves recorded a sharp decrease at wavelengths slightly below $400 \mathrm{~nm}$ which agrees with the reports of [14] for ZnSe films. The sharp decrease observed in the absorption spectra of ZnSe:Eu films at wavelengths less than $400 \mathrm{~nm}$ can be attributed to the onset of inter-band transitions at the fundamental band edge [15].

The transmittance values for all the deposited films were evaluated from the absorbance values from the relation [16]:

$$
T=10^{-A} .
$$

In equation (5), $T$ is the transmittance of the material under investigation while $A$ represents the absorbance. The transmission spectra for $\mathrm{ZnSe}: \mathrm{Eu}$ films are presented in Fig. 2.

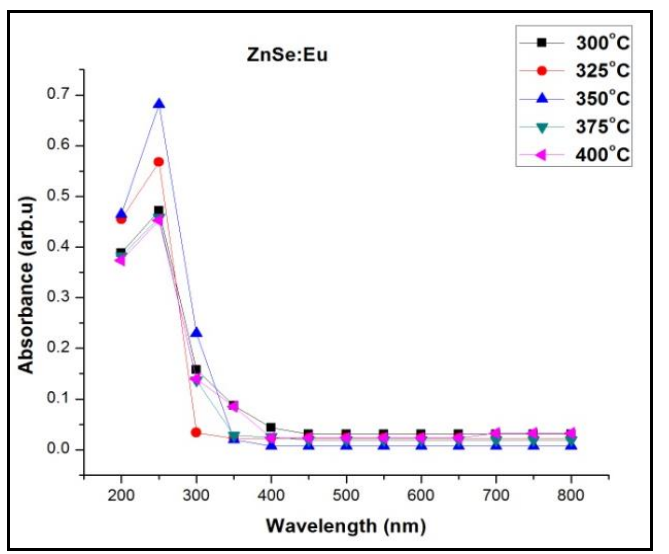

Fig. 1 - ZnSe:Eu films absorption spectra at different deposition temperatures

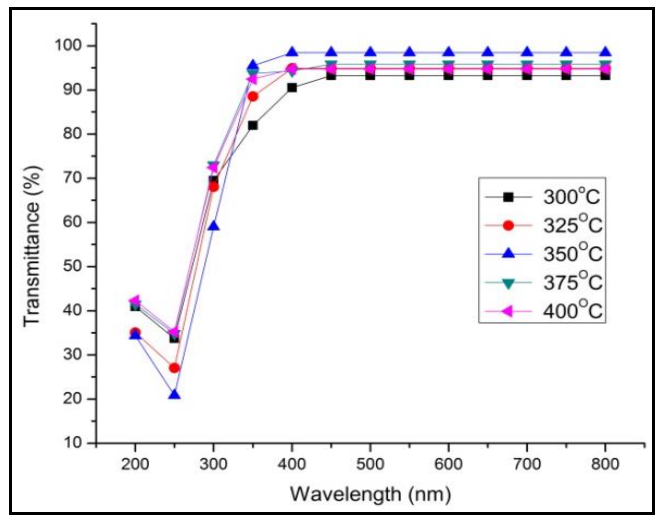

Fig. 2 - Transmission spectra of Eu-doped ZnSe films at various temperatures

From Fig. 2, the transmission spectra of all ZnSe:Eu films were between $59 \%$ and $72 \%$ in the UV region, while the films exhibited very high transparency (91\% to $98 \%$ ) in the visible region at different deposition conditions (temperature), which suggests the material's suitability for fabricating transparent products. Airplane windows need to be extremely free from ice and also need to be highly transparent particularly in cold air and all flying conditions. This condition is very crucial for safe take-off and flying in cold air, as well as 
shielding planes from electromagnetic interference and maintaining transparency in demanding conditions [17]. This high transmittance exhibited by Eu-doped ZnSe films indicates that ZnSe:Eu will prove absolutely useful in coating airplane windows to help maintain transparency at all weather conditions and to maintain a safe flight.

The reflectance values for all europium-doped $\mathrm{ZnSe}$ films being studied were calculated from the absorbance and transmittance values from the relation [1]:

$$
\begin{aligned}
& A+T+R=1, \\
& R=1-[A+T] .
\end{aligned}
$$

The reflection spectra of Eu-doped ZnSe films are presented in Fig. 3.

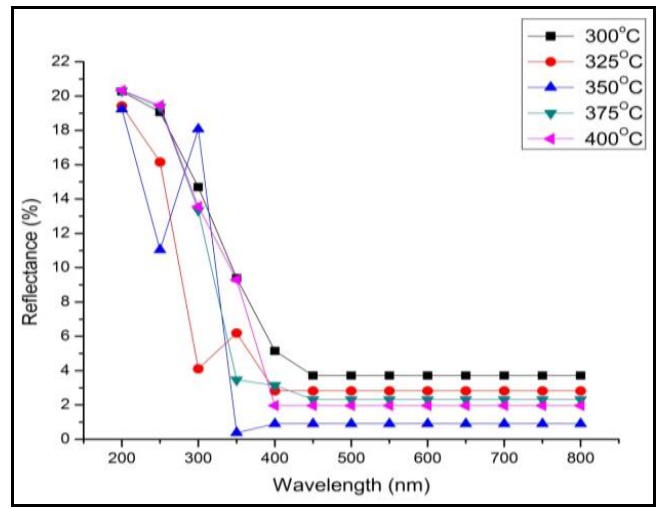

Fig. 3 - Reflection spectra of Eu-doped ZnSe films at different deposition temperatures

Fig. 3 is suggestive that ZnSe:Eu films are poorly reflective in the ultra-violet and visible regions. Previous researchers [5, 13] have also reported low reflectance values for $\mathrm{ZnSe}$ films. Reflectance values of ZnSe:Eu films obtained for different deposition temperatures are between $0.9 \%$ and $20.33 \%$. The low values of reflection in all cases of the investigated films at overall spectral ranges testify their probability of usage as an anti-reflective coating in high efficiency solar cells [11].

The refractive indices of $\mathrm{ZnSe}: \mathrm{Eu}$ films were analyzed at different deposition temperatures from reflectance values from the relation $[1,16]$ :

$$
n=\frac{1+R^{1 / 2}}{1-R^{1 / 2}} .
$$

Fig. 4 reveals the plot of refractive index versus photon energy at different deposition temperatures for ZnSe:Eu films.

From Fig. 4, the refractive index of ZnSe:Eu films at different deposition temperatures reveals a constant value of about 1.06 to 1.88 at photon energies below $4 \mathrm{eV}$. However, at high photon energies, the films recorded high refractive index between 2.24 and 2.64 for the range of temperatures $\left(300{ }^{\circ} \mathrm{C}\right.$ to $\left.400{ }^{\circ} \mathrm{C}\right)$ under investigation. This property of high refractive index exhibited by the films at high photon energies suggests that they will be useful in the manufacture of optoelectronic devices.

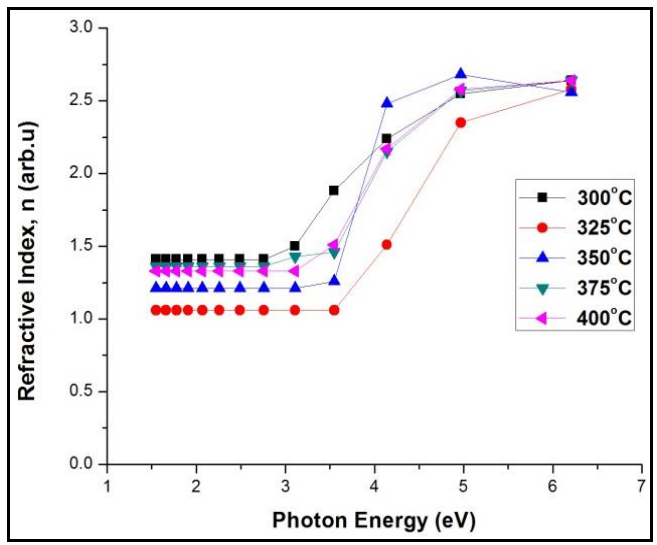

Fig. 4 - Variation of the refractive index of ZnSe:Eu films with temperature

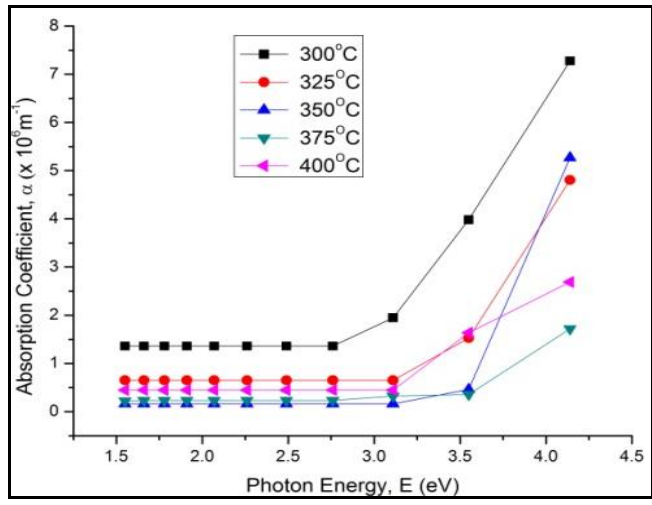

Fig. 5-Absorption coefficient of ZnSe:Eu films at different deposition temperatures

The absorption coefficient values of $\mathrm{ZnSe}: \mathrm{Eu}$ films at different deposition temperatures were calculated from the relation [1]:

$$
\alpha=\frac{-(\ln T)}{t},
$$

where $t$ and $T$ represent thickness and transmittance.

A similar trend is observed for all $\mathrm{ZnSe:Eu}$ films. An almost steady value is observed at photon energies below $3 \mathrm{eV}$ and increases afterwards. This behavior simply implies that the material possesses high absorbance at short wavelengths and low absorbance values at longer wavelengths. The values of absorption coefficient are very large, which is a consequence of the very large density of states in the solid phase [18].

The optical conductivity of ZnSe:Eu films under study was calculated for different deposition temperatures.

ZnSe:Eu films at different deposition temperatures exhibited a steady high optical conductivity at small photon energies (corresponding to the visible region) and thereafter, the films exhibited some form of sudden increment at photon energy over $3 \mathrm{eV}$ (about $3.5 \mathrm{eV}$ ), except for the film deposited at substrate temperature of $300{ }^{\circ} \mathrm{C}$ which increased at a photon energy of about $2.8 \mathrm{eV}$. For semiconductors, the optical conductivity increases sharply for higher photon energy which satisfactorily agrees with the results reported in this research.

Extinction coefficient plot of $\mathrm{ZnSe}: \mathrm{Eu}$ films is seen in Fig. 7. 


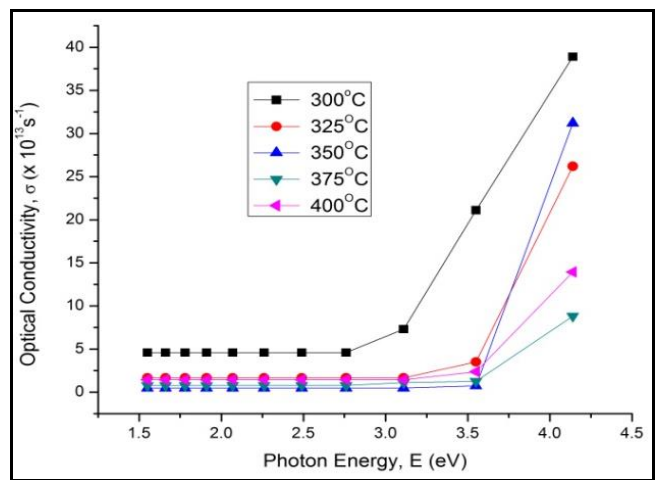

Fig. 6 - Optical conductivity variation of $\mathrm{ZnSe:Eu} \mathrm{films} \mathrm{with}$ temperature

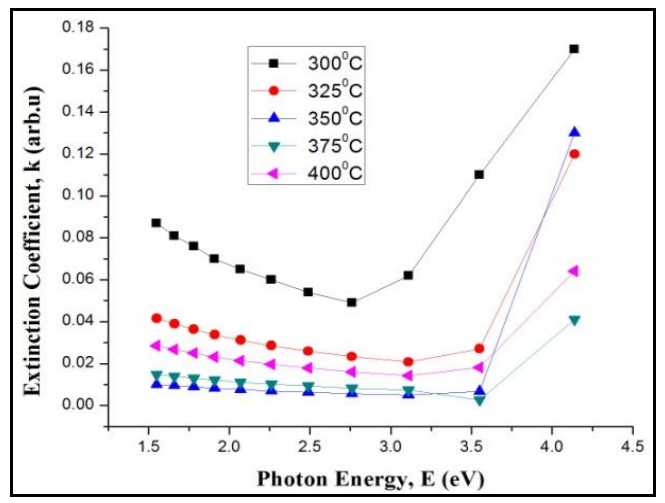

Fig. 7 - Extinction coefficient plot of ZnSe:Eu films at different deposition temperatures

By carefully examining Fig. 7, one discovers that the extinction coefficient of ZnSe:Eu films gradually decreased with an increase in photon energy before increasing spontaneously. The sharp increase of extinction coefficient with photon energy indicates the probability of raising the electron transfer across the mobility gap with high photon energy and greater attenuation of light [19].

Fig. 8 shows a plot of the real part of the dielectric constant for ZnSe:Eu films for different deposition temperatures.

For all deposited ZnSe:Eu films, the real dielectric constant assumes a constant value at low photon energy (visible region) and increases spontaneously above $2.5 \mathrm{eV}$ near the UV region (Fig. 8).

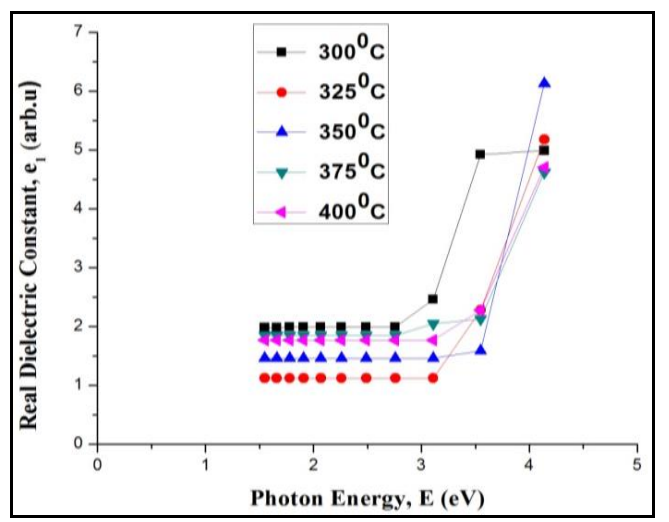

Fig. 8 - Real dielectric constant plot of ZnSe:Eu films at different temperature variations

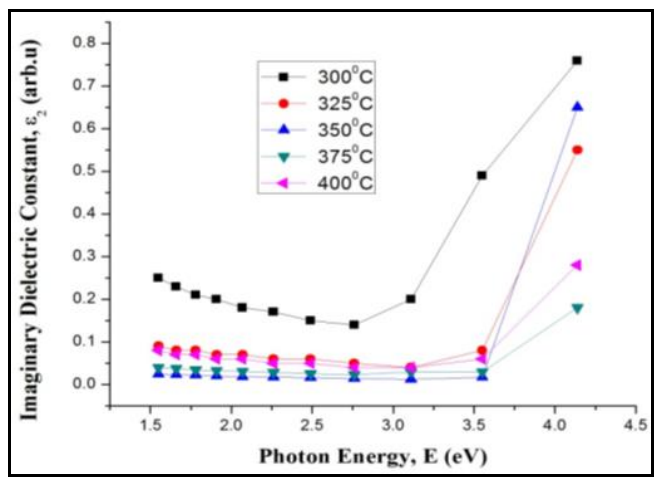

Fig. 9 - Imaginary dielectric constant plot of ZnSe:Eu films at different deposition temperatures

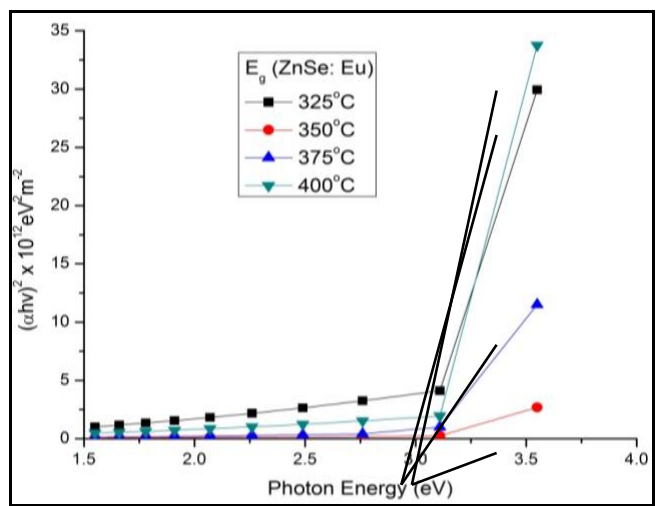

Fig. 10 - Plot of $(\alpha h v) 2$ versus photon energy for ZnSe:Eu films at different deposition temperatures

The imaginary dielectric constant of ZnSe:Eu films was analyzed and the plot is displayed in Fig. 9.

The imaginary dielectric constant values of $\mathrm{ZnSe}: \mathrm{Eu}$ films assume a steady decline as the photon energy approaches higher values (UV region). Nevertheless, the films exhibited steep increase around $2.8 \mathrm{eV}$ (for the film at $300{ }^{\circ} \mathrm{C}$ ) and about $3.4 \mathrm{eV}$ (for films at 325 to $400{ }^{\circ} \mathrm{C}$ ).

The energy gap (direct) of ZnSe:Eu films was analyzed from the equation [20]:

$$
(\alpha h v)=C\left(h v-E_{g}\right)^{n},
$$

where $C$ is a constant, $n$ represents the type of transition. For a direct transition, $n=1 / 2$, while for an indirect transition $n$ is $2, E_{g}$ is the band gap energy while $h v$ represents the photon energy in electron volts.

The energy band gap of $\mathrm{ZnSe:Eu} \mathrm{films} \mathrm{at} \mathrm{different}$ deposition temperatures was obtained from the plot of $(\alpha h v)^{2}$ versus photon energy, and the band gap is obtained by extrapolating the linear section of the curve to the point where $(\alpha h v)^{2}$ equals zero.

Fig. 10 shows the plot of $(\alpha h v)^{2}$ versus photon energy for ZnSe:Eu films for different deposition temperatures.

As observed in Fig. 10, for all deposition temperatures, blue-shift ( $3.01 \mathrm{eV}$ to $3.12 \mathrm{eV}$ ) is observed for the band gap of ZnSe:Eu when compared with that (about $2.72 \mathrm{eV}$ ) of bulk ZnSe. The strong blue-shift exhibited by the films is an indication of quantum confinement effect taking place at the nanoscale level which is responsible for the increment in energy band gap. The quantum size effect increases the energy of electrons and hence shifts the effective band gap to higher ener- 
gy [18]. The values of energy gap for $\mathrm{ZnSe:Eu} \mathrm{obtained}$ in this research are close to those reported in earlier studies [8] for ZnSe.

\section{CONCLUSIONS}

Eu-doped ZnSe nano/thin films were deposited on glass substrate using electrostatic spray pyrolysis technique at different deposition temperatures. Depending on the substrate temperature, energy band gap varied between $3.01 \mathrm{eV}$ and $3.12 \mathrm{eV}$ indicating a strong blueshift from the bulk value $(2.72 \mathrm{eV})$ of $\mathrm{ZnSe}$. The strong blue-shift exhibited by the films is an indication of the presence of quantum confinement at the nanoscale level which is responsible for the increment in energy band gap. Optical study results (high refractive index) of nano/thin films reveals that ZnSe:Eu nano/thin films can be employed in the fabrication of optoelectronic devices including LEDs, LCDs, etc.

\title{
REFERENCES
}

1. M.D. Jeroh, D.N. Okoli, Int. J. Res. Rev. Appl. Sci. 12, 431 (2012).

2. C.I. Nweze, A.J. Ekpunobi, Int. J. Sci. Technol. Res. 3, (2014).

3. P.C. Pingale, S.T. Mane, R.V. Suryawanshi, L.P. Deshmukh, Adv. Appl. Sci. Res. 4, 177 (2013).

4. M. Kumar, Ind. J. Appl. Res. 5, 511 (2015).

5. G.M. Lohar, S.K. Shinde, V.J. Fulari, J. Semicond. 35, 1 (2014).

6. U. Khairnar, S. Behere, P. Pawar, Mater. Sci. Appl. 3, 36 (2012).

7. H.H. Yudar, S. Pat, S. Korkmaz, S. Özen, V. Şenay, J. Mater. Sci. Mater. Electron. 28, 2833 (2017).

8. I. Ahemen, A.N. Amah, D.B.E. Attab, A.Y. Fasasi, Nanosci. Nanotechnol. 4, 7 (2014).

9. P.M. Aneesh, M.K. Jayaraj, Bull. Mater. Sci. 33, 227 (2010).

10. P. Kumar, K. Singh, Curr. Nanosci. 6, 402 (2010).

11. M.M. Ivashchenko, A.S. Opanasyuk, I.P. Buryk, V.A. Lutsenko, A.V. Shevchenko, J. Nano- Electron. Phys. 9, 01011 (2017).

12. S.J. Gnanamuthu, S.J. Jeyakumar, A.R. Balu, K. Usharani, V.S. Nagarethinam, Int. J. Thin Film. Sci. Technol. 2, 121 (2015).

13. H.N. Desai, J.M. Dhimmar, B.P. Modi, Int. J. Eng. Res. Appl. 5, 117 (2015).

14. A. Kathalingam, T. Mahalingam and C. Sanjeeviraja, Mater. Chem. Phys. 106, 215 (2007).

15. F. Ozutok, K. Erturk, V. Bilgin, Acta Phys. Pol. A 121, 221 (2012).

16. D.D.O. Eya, A.J. Ekpunobi, C.E. Okeke, Pacific J. Sci. Technol. 6, 16 (2005)

17. G. Popkin, Amer. Phys. Soc. 25, 1 (2016).

18. M. Fox, Optical Properties of Solids (Oxford Uni. Press: New York: 2001).

19. H. Howari, J. Natl, Sci. Math. 5, 139 (2012).

20. L. Gao-Ren, Y. Chen-Zhong, L. Xi-Hong, Z. Fu-Lin, F. ZhanPing, Y. Xiao-Lan, S. Cheng-Yong, T. Ye-Xiang, Chem. Mater. 20, 3306 (2008)

\section{Оптичні властивості плівок селеніду цинку, які леговані европіем}

\author{
D.M. Jeroh, A.J. Ekpunobi, D.N. Okoli
}

Nnamdi Azikiwe University, Anambra State, Nigeria

\begin{abstract}
Плівки ZnSe, які леговані европіем, електростатично розпилювались на скляні підкладки. Зберігаючи постійними інші параметри осадження, такі як швидкість потоку розчину прекурсора, об'єм розпилення, напруга та відстань сопла до основи, температура варіювалась приблизно від $300{ }^{\circ} \mathrm{C}$ та $400{ }^{\circ} \mathrm{C}$ з інтервалом 25 градусів. Оптичні дослідження представлені при різних температурах. Товщина плівок вказуе на нанорозміри і складае 50, 100, 150, 75 і 60 нм у зазначеному діапазоні температур. Оптичні дослідження виявляють високу прозорість і дуже низькі характеристики поглинання та відбиття плівок ZnSe:Eu у видимому діапазоні. Піки поглинання, видимі при 250 нм, припускають появу дефектного стану біля краю смуги. Спостерігаеться високий коефіцієнт поглинання, який свідчить про високу густину станів у ZnSe:Еu. Високий коефіщіент пропускання свідчить про придатність плівок в матеріалах покриттів, від яких вимагаеться висока прозорість для лазерних застосувань, тоді як низькі значення коефіціента відбиття та великий показник заломлення показують, що плівки можуть бути застосовані в покриттях сонячних елементів, що вимагає високої ефективності, та для виробництва оптоелектронних пристроїв. Є очевидною вища оптична провідність при енергіях фоотонів більше 3 еВ. Різке збільшення коефіціента екстинкції з енергією фотонів вказуе на збільшення ймовірності переносу електрона через зону рухливості з високою енергією фотонів і більшим ослабленням світла. Дослідження забороненої зони плівок ZnSe:Eu виявляе сильний синій зсув (з 3,01 еB до $3,12 \mathrm{eB})$ від положення забороненої зони об’ємного ZnSe $(2,72 \mathrm{eB})$.
\end{abstract}

Ключові слова: Селенід цинку, Свропій, Наноплівки, Спрей-піроліз, Оптичні дослідження. 